\title{
Pemeliharaan Dan Penyimpanan Peralatan Laboratorium Kimia
}

\author{
Jufriyaha $^{a}$, Isna Mar'ah ${ }^{b}$, Kelik Isharyudono ${ }^{c}$ \\ ${ }^{a}$ Laboratorium Mikrobiologi Industri Departemen Teknik Kimia \\ Fakultas Teknik Universitas Diponegoro, Semarang \\ E-mail : jufie.sucipto@che.undip.ac.id \\ ${ }^{b}$ Laboratorium Kimia Organik Departemen Kimia \\ Fakultas Sains dan Matematika Universitas Diponegoro, Semarang \\ E-mail : giovaniisna@yahoo.com \\ ${ }^{c}$ Laboratorium Ilmu Nutrisi dan Pakan Departemen Peternakan, \\ Fakultas Peternakan dan Pertanian,Universitas Diponegoro Semarang \\ E-mail :kakafachri@gmail.com
}

Received: $24^{\text {th }}$ October 2018; Revised: $18^{\text {th }}$ November 2018; Accepted: $19^{\text {th }}$ December 2018;

Available online: $24^{\text {th }}$ December 2018; Published regularly: January 2019

\begin{abstract}
Improper maintenance and storage of laboratory equipment, will shorten the life span. Damage to the tool will have a direct impact on the costs that must be incurred to replace damaged equipment components or even procurement of new equipment. The purpose of this paper is to provide an understanding of how to maintain and store chemical laboratory equipment. And can identify damage to chemical laboratory equipment.

Broadly speaking, the tool maintenance method is divided into two parts: planned maintenance and unplanned maintenance. For storage of tools using the classification method based on the tool group, frequency of use and the nature of the tool.

Maintenance and storage of chemical laboratory equipment is an activity process in order to anticipate damage as early as possible so that it can increase the efficiency of the working life of the equipment used.

So that the chemical laboratory equipment can function optimally and always in a state of ready use, it is necessary to have knowledge about how to maintain and store laboratory equipment and how to identify equipment damage as early as possible. Maintenance and storage of chemical laboratory equipment properly can prevent damage to chemical laboratory equipment that will extend the life of the equipment, and ensure the comfort and safety of the user.
\end{abstract}

Keywords: chemistry, laboratory, maintenance, storage, equipment

\begin{abstract}
Abstrak
Pemeliharaan dan penyimpanan alat laboratorium yang tidak tepat, akan memperpendek usia pakai. Kerusakan pada alat akan berakibat langsung pada biaya yang harus dikeluarkan untuk mengganti komponen peralatan yang rusak atau bahkan pengadaan alat baru. Tujuan dari pembuatan makalah ini adalah untuk memberi pemahaman tentang cara pemeliharaan dan penyimpanan alat laboratorium kimia. Serta dapat mengidentifikasi kerusakan alat laboratorium kimia.

Secara garis besar metode pemeliharaan alat dibagi menjadi 2 bagian yaitu pemeliharaan terencana dan pemeliharaan tak terencana. Untuk penyimpanan alat menggunakan metode klasifikasi berdasarkan kelompok alat, frekuensi penggunaan, dan sifat alat.

Pemeliharaan dan penyimpanan peralatan laboratorium kimia merupakan suatu proses kegiatan dalam rangka mengantisipasi terjadinya kerusakan sedini mungkin sehingga dapat meningkatkan efisiensi masa kerja peralatan yang digunakan.

Supaya alat laboratorium kimia dapat berfungsi secara optimal dan selalu dalam keadaan siap pakai, maka sangat perlu adanya pengetahuan mengenai cara pemeliharaan dan penyimpanan alat laboratorium dan cara
\end{abstract}


mengidentifikasi kerusakan alat sedini mungkin. Pemeliharaan dan penyimpanan peralatan laboratorium kimia dengan baik dapat mencegah terjadinya kerusakan pada peralatan laboratorium kimia yang akan memperpanjang usia pakai alat, serta menjamin kenyamanan dan keamanan pengguna.

Kata kunci : kimia, laboratorium, pemeliharaan, penyimpanan, peralatan

\section{PENDAHULUAN}

Laboratorium adalah unit penunjang akademik pada lembaga pendidikan, berupa ruangan tertutup atau terbuka, bersifat permanen atau bergerak, dikelola secara sistematis untuk kegiatan pengujian, kalibrasi, dan/atau produksi dalam skala terbatas, dengan menggunakan peralatan dan bahan berdasarkan metode keilmuan tertentu, dalam rangka pelaksanaan pendidikan, penelitian, dan/atau pengabdian kepada masyarakat (Permen No 145 Tahun 2014).

Peranan laboratorium sangat besar sebagai sumber belajar yang efektif untuk mencapai kompetensi yang diharapkan oleh pengguna laboratorium. Untuk mengoptimalkan fungsi laboratorium, maka laboratorium perlu dikelola dengan baik sehingga mendorong semangat kerja mahasiswa, dosen, dan pengguna lainnya. Agar bekerja di laboratorium merasa aman dan nyaman, maka laboratorium berikut sarana lainnya perlu dikelola dan dipelihara secara rutin, sehingga dapat berfungsi seoptimal mungkin.

Kerusakan yang terjadi pada peralatan laboratorium dapat dicegah dengan melakukan upaya pemeliharaan dan penyimpanan peralatan secara rutin dan teratur. Disadari atau tidak, kerusakan pada peralatan laboratorium akan berakibat langsung kepada biaya yang besar untuk mengganti komponen peralatan yang rusak.

Agar peralatan di laboratorium selalu dalam keadaan siap untuk dipakai, maka diperlukan pemeliharaan dan penyimpanan peralatan laboratorium yang baik.

\section{BAHAN DAN METODE}

Tujuan dari makalah ini adalah agar dapat memahami teknik pemeliharaan alat laboratorium., Memahami cara penyimpanan alat laboratorium., Dapat mengidentifikasi kerusakan alat laboratorium.

\section{Manfaat}

Manfaat dari makalah ini adalah untuk memberikan pengetahuan mengenai cara pemeliharaan dan penyimpan peralatan laboratorium dengan baik.

\section{HASIL DAN PEMBAHASAN}

Pemeliharaan adalah suatu bentuk tindakan yang dilakukan untuk menjaga agar suatu alat selalu dalam keadaan siap pakai, atau tindakan melakukan perbaikan sampai pada kondisi alat dapat berfungsi kembali. Perawatan adalah kegiatan yang dilakukan untuk meningkatkan, mempertahankan, dan mengembalikan peralatan dalam kondisi yang baik dan siap pakai.

Pada umumnya pemeliharaan di bagi atas dua bagian, yaitu pemeliharaan terencana dan pemeliharaan tak terencana. Pemeliharaan terencana (planned maintenance) didefinisikan sebagai proses pemeliharaan yang diatur dan diorganisasikan untuk mengantisipasi perubahan yang terjadi terhadap peralatan di waktu yang akan datang. Di dalam pemeliharaan terencana, terdapat unsur pengendalian dan unsur pencatatan sesuai dengan rencana yang telah ditentukan sebelumnya. Pemeliharaan terencana adalah sistem pengorganisasian pemeliharaan atau program pemeliharaan yang dikelola dengan cara yang efektif. Pemeliharaan terencana adalah jenis pemeliharaan yang diprogramkan, diorganisir, dijadwalkan, dianggarkan, dan dilaksanakan sesuai dengan rencana, serta dilakukan monitoring dan evaluasi.

Pemeliharaan tidak terencana adalah jenis pemeliharaan yang bersifat perbaikan terhadap kerusakan yang tidak diperkirakan sebelumnya. Pekerjaan pemeliharaan ini tidak direncanakan, dan tidak dijadwalkan. Umumnya tingkat kerusakan yang terjadi adalah pada tingkat kerusakan berat. Karena tidak direncanakan sebelumnya, maka juga disebut pemeliharaan darurat. 
Waktu untuk pemeliharaan peralatan laboratorium dapat dilihat dari tersedianya kesempatan atau waktu bagi pihak yang dilibatkan dalam kegiatan pemeliharaan dan pemanfaatan kesempatan tersebut secara efektif dan efisien untuk melaksanakan kegiatan pemeliharaan. Dari sisi obyek yang dipelihara, jadwal pelaksanaan pekerjaan pemeliharaan laboratorium dapat ditetapkan berdasarkan pada :

Berdasarkan jenis pekerjaan pemeliharaan alat. Bagi PLP yang telah berpengalaman dalam melakukan tugas pemeliharaan peralatan laboratorium akan banyak memiliki informasi untuk membantu dalam menyusun jadwal pemeliharaan, Berdasarkan sifat operasi atau beban pemakaian atau penggunaan peralatan laboratorium. Untuk obyek atau alat yang sering digunakan pada kegiatan praktikum dan pemakainya banyak orang, maka obyek atau alat tersebut akan cepat kotor atau rusak. Untuk menjaga agar tetap bersih dan menghindari kerusakan, mestinya jadwal pemeliharaan harus dibuat tinggi frekuensinya yang berarti obyek atau alat tersebut harus sering dilakukan pemeliharaan., Berdasarkan rekomendasi dari pabrik pembuat peralatan yang dimiliki laboratorium. Peralatan laboratorium yang baru dibeli dari pabrik biasanya dilengkapi dengan buku manual yang membuat petunjuk operasi dan cara serta jadwal pemeliharaan alat tersebut. Informasi tersebut dapat dipakai sebagai rujukan dalam menyusun jadwal peralatan.

Di laboratorium kimia alat-alat praktikum kimia dikelompokkan kedalam 8 golongan, yaitu:

Golongan I: Alat-alat yang terbuat dari bahan gelas/kaca seperti: tabung reaksi, batang pengaduk, gelas kimia, erlenmeyer, gelas ukur, labu ukur, corong dan lain-lain.

Golongan II : Alat-alat yang terbuat dari besi, contoh; kaki tiga, pembakar, tang cawan, kawat kasa, ring besi, klem pemegang, klem buret, penjepit tabung, sikat tabung, pemadam kebakaran, dsb.

Golongan III: Alat-alat yang terbuat dari kayu, contoh; rak tabung, rak pipet volumetrik, rak buret, penjepit tabung, dsb

Golongan IV: Alat-alat yang terbuat dari bahan porselen, contoh cawan porselin, lumpang dan alu, bak pembakaran porselen, segitiga, tungku listrik, pelat tetes dsb.

Golongan V: Alat-alat yang terbuat dari plastik, contoh: pompa suntik (siringe), gelas kimia plastik, gelas ukur plastik, botol semprot, selang plastik, dsb.

Golongan VI: Alat-alat yang terbuat dari karet, contoh: pompa filler, selang karet, sumbat botol, sarung tangan dan lain-lain.

Golongan VII: Alat-alat listrik, contoh; power supply, amperemeter, voltmeter, multimeter, neraca listrik. Golongan VIII: Alat-alat kimia yang memerlukan penyimpanan khusus contoh; buret, thermometer, neraca, spektrofotometer, dsb.

Penyimpanan juga dapat dilakukan berdasarkan atas bahan dasar alat, misalnya alat-alat dari gelas disimpan menjadi satu kumpulan, demikian pula alat-alat dari bahan kayu, besi, porselein dan sebagainya. Tetapi jika sistem ini yang diambil, kadang-kadang kita sukar menentukan kumpulan alat jika sebuah alat terbuat dari beberapa bahan yang berlainan. Walaupun demikian, sistem apapun yang digunakan dalam penyimpanan alat, maka alat-alat itu harus dalam keadaan aman, mudah dicari dan diambil.

Statif besi yang sering banyak digunakan hendaknya disimpan di atas meja pada sudut laboratorium dengan demikian mudah diambil dan dikembalikan. Hendaknya statif ini jangan disimpan di bagian bawah lemari asap atau diletakkan di atas lantai, karena akan mudah kena debu dan kurang mendapat perhatian.

Penyimpanan pipet kadang-kadang juga merupakan masalah. Sebaiknya pipet disimpan dalam keadaan berdiri, oleh sebab itu perlu diletakkan pada tempat yang khusus. Meletakkan pipet dengan cara berdiri membuat pipet akan cepat kering dan siap untuk segera dipakai. Jika pipet dan buret tidak sering dipakai hendaknya penyimpanannya ditempat yang tertutup sehingga debu tidak melekat padanya. Pada saat melakukan praktikum dimana mahasiswa diharuskan mengambil sendiri, biasanya pipet dapat diletakkan pada meja mahasiswa dimana praktikum akan dilakukan. 


\section{Pemeliharaan Alat}

Pemeliharaan peralatan laboratorium memiliki beberapa tujuan yang mencakup:

Peralatan laboratorium selalu prima, dan siap pakai secara optimal, Memperpanjang umur pemakaian peralatan laboratorium, Menjamin keamanan, keselamatan, dan kenyamanan orang atau mahasiswa yang menggunakan peralatan tersebut, Menjamin kesiapan operasional peralatan yang diperlukan terutama dalam keadaan darurat, adanya unit cadangan, pemadam kebakaran, dan penyelamat, Mengetahui kerusakan secara dini atau gejala kerusakan, Menghindari terjadinya kerusakan secara mendadak, Menghindari terjadinya kerusakan fatal.

Cara atau metode untuk melakukan pekerjaan pemeliharaan peralatan laboratorium yang dapat dilakukan antara lain dengan cara:

Melakukan pencegahan, misalnya dengan memberi peringatan melalui gambar atau tulisan, peraturan, tata tertib bagi pengguna laboratorium, dan memberi bahan pengawet.

Menyimpan, misalnya menyimpan peralatan laboratorium agar terhindar dari kerusakan.

Membersihkan, agar peralatan laboratorium selalu bersih dari kotoran yang dapat merusak, misalnya debu dan uap air yang dapat menyebabkan terjadinya korosi.

Memelihara, misalnya dengan melumasi peralatan mekanis.

Memeriksa atau mengecek kondisi peralatan laboratorium untuk mengetahui adanya gejala kerusakan.

Menyetel kembali atau tune-up, kalibrasi alat agar fasilitas atau peralatan dalam kondisi normal atau standar.

Memperbaiki kerusakan ringan yang terjadi pada peralatan laboratorium pada batas tingkat kerusakan tertentu yang masih mungkin dapat diperbaiki sendiri, sehingga siap pakai.

Mengganti komponen-komponen peralatan laboratorium yang rusak.

Keberhasilan suatu percobaan kimia tergantung pada ketelitian bekerja dan penggunaan alat-alat yang bersih. Alat-alat yang bersih sangat diperlukan untuk mencapai keberhasilan percobaan. Gelas ukur, pipet, buret yang kotor dapat menghasilkan pengukuran yang salah. Biasakan alat-alat yang berada di dalam laboratorium disimpan secara rapi dan dalam keadaan bersih. Biasakan membersihkan alat-alat segera setelah dipakai. Umumnya, alat-alat yang baru dipakai mudah dibersihkan. Alat-alat kaca seperti tabung reaksi, gelas ukur, gelas kimia, labu erlenmeyer, dan pipet setelah dipakai dapat dibersihkan dengan larutan detergen atau air sabun, kemudian dibilas dengan air leding. Dalam beberapa hal alat-alat ini perlu lagi dibilas dengan air suling. Alat-alat kaca yang mengandung sisa-sisa zat kimia bila tidak segera dibersihkan dapat menyebabkan noda-noda pada kaca tersebut sukar atau tidak dapat dibersihkan dengan larutan detergen atau air sabun. Makin lama noda melekat pada kaca, makin sukar noda itu dibersihkan.

Untuk menjaga dari kerusakan alat perlu diketahui sifat-sifat dasar dari alat tersebut, antara lain:

Zat atau Bahan Dasar Pembuatan

Bahan dasar alat harus diketahui agar penyimpanan dan penggunaanya dapat dikontrol. Misalnya alat gelas yang akan dipakai untuk pemanasan harus dipilih dari bahan yang tahan panas. Bila suatu alat terbuat dari besi, atau sebagian pelengkap alat terbuat dari besi, maka tidak boleh disimpan berdekatan dengan zat-zat kimia, terutama yang bersifat korosif. Bahan besi dengan asam akan cepat berkarat.

Berat Alat

Di laboratorium terdapat alat yang ringan dan ada yang berat. Untuk alat-alat berat jangan disimpan di tempat yang tinggi, sehingga sewaktu mau menyimpan atau mengambil tidak sulit diangkat atau dipindahkan.

Kepekaan Alat Terhadap Pengaruh Lingkungan

Berbagai alat seperti mikroskop yang peka terhadap lingkungan, misalnya terhadap kelembaban, di daerah yang dingin atau di daerah yang lembab penyimpanan harus hati-hati, karena pada daerah lembab bila alat disimpan dalam lemari kemungkinan besar akan ditumbuhi jamur. Lensa harus dijaga jangan sampai berjamur. Lensa obyektif dan okuler cepat berjamur di daerah lembab. Salah satu cara mencegah pengaruh 
kelembaban di lemari penyimpanan dipasang lampu listrik, sehingga udara dalam lemari menjadi lebih kering. Mikroskop harus disimpan dalam kotaknya dan diberi zat absorpsi (silika gel).

Pengaruh Bahan Kimia

Dalam laboratorium terdapat zat-zat kimia. Beberapa zat kimia terutama yang korosif dapat mempengaruhi atau merusak alat. Oleh karena itu zat-zat kimia harus disimpan berjauhan dari alat-alat, terutama alat-alat yang terbuat dari logam. Alat alat yang menggunakan baterai kering bila selesai digunakan baterai harus dikeluarkan, dan alat harus disimpan dalam keadaan turn of (sleep). Misalnya : $\mathrm{pH}$ meter, komparator lingkungan.

Pengaruh alat yang satu dengan yang lain

Dalam penyimpanan alat perlu diperhatikan bahwa alat yang terbuat dari logam harus dipisahkan dari alat yang terbuat dari gelas. Beberapa alat yang diset dan terdiri dari alat logam dan kaca, misalnya Respirometer Sederhana, dan Potometer. Selain alat itu sendiri, dibutuhkan standarnya. Setiap alat yang terkombinasi dari logam-kaca, sedapat mungkin dalam penyimpanannya dipisahkan, pada waktu hendak dipakai barulah dipasang atau diset. Magnet jangan disimpan dekat alat-alat yang sensitif pada magnet. Stopwatch dapat kehilangan kestabilan bila disimpan berdekatan dengan magnet.

Nilai atau harga dari alat

Nilai atau harga alat harus diketahui oleh petugas laboratorium, atau setidaknya petugas laboratorium harus dapat menilai mana barang yang mahal, dan mana barang yang murah. Ditinjau dari segi harganya alat-alat berharga mahal harus disimpan pada tempat yang aman atau lemari yang pakai kunci. Barang yang nilainya tidak begitu mahal dapat disimpan pada rak atau tempat terbuka lainnya. Akan tetapi bila ada tempat atau lemari tertutup sebaiknya semua alat disimpan dalam lemari tersebut.

Bentuk dalam set

Jenis alat dalam penggunaannya menggunakan energi bentuk set misalnya set blood meter. Untuk menjaga keawetan alat, bila telah selesai digunakan hendaknya disusun kembali pada tempat semula dengan susunan aturan yang telah ditentukan.

Di Laboratorium bentuk alat juga beraneka ragam. Banyak alat yang bentuknya bundar, alat ini harus disimpan sebaik mungkin, jangan sampai terguling. Ada alat yang harus disimpan dalam keadaan berdiri, misalnya hygrometer. Cara menyimpan alat ini sebaiknya dalam keadaan tergantung. Beberapa jenis thermometer mempunyai tempat khusus (tabung). Setelah selesai dipergunakan dibiasakan menyimpan atau segera dimasukkan dalam tabungnya.

Pemeliharaan alat secara rutin dapat dilakukan. Sebelum alat digunakan hendaknya diperiksa dulu kelengkapannya dan harus dibersihkan terlebih dahulu. Setelah selesai dipergunakan semua alat harus dibersihkan kembali dan jangan disimpan dalam keadaan kotor. Demikian juga kelengkapan alat tersebut harus dicek terlebih dahulu sebelum disimpan. Lemari untuk menyimpan alat seringkali terkena rayap, untuk mencegah rayap yang dapat merusak berbagai jenis alat, maka secara periodik perlu disemprot dengan anti rayap atau sejenisnya atau dengan memasukkan kapur barus pada lemari penyimpanan.

Setiap alat yang penggunaannya agak rumit harus mempunyai buku petunjuk atau keterangan penggunaan. Maka sebelum alat digunakan hendaknya dibaca terlebih dahulu petunjuk penggunaan alat dan petunjuk pemeliharaan. Peralatan praktikum di laboratorium juga terdapat alat yang terbuat dari bahan kaca. Agar alat-alat ini siap pakai,, alat harus dalam keadaan bersih. Untuk mendapatkan alat kaca yang bersih diperlukan perawatan yang teratur, yang meliputi pengecekan, penyimpanan yang benar, dan pencucian.

Pencucian Alat Kaca Umum

Alat-alat kaca yang tidak terlalu kotor dapat dibersihkan dengan cara pencucian umum, yaitu dengan air (jika perlu air hangat) dan sedikit detergen.

Pada waktu mencuci alat kaca, gunakan sarung tangan dan alat bantu lain, misalnya sikat tabung. Jika pada alat kaca terdapat noda yang agak kuat melekat, noda ini dapat dihilangkan dengan bubuk pencuci yang sesuai, misalnya trinatrium fosfat yang dicampur dengan sedikit bubuk batu apung. Jika perlu gunakan alcohol atau aseton. Setelah pencucian dengan zat pencuci, alat kaca dibilas dengan air bersih dan terakhir 
dibilas lagi dengan air suling. Jika alat kaca yang baru dicuci akan segera digunakan untuk praktikum, bilas lat kaca itu dengan aseton dan spiritus dan untuk pengeringan yang cepat dapat digunakan udara panas yang ditiupkan dari kompresor.

Pencucian Alat Kaca Khusus

Alat kaca yang terkontaminasi dengan noda-noda tertentu yang sukar dibersihkan dengan air dan detergen memerlukan pencucian dengan larutan pencuci tertentu sebagai perlakuan akhir setelah alat tersebut dicuci dengan cara pencucian umum. Larutan yang umum digunakan untuk mencuci noda-noda tertentu dapat dibuat di laboratorium. Larutan pencuci ini hendaknya selalu tersedia dan siap dipakai. Kekuatan/daya pencuci dalam membersihkan noda tergantung pada kekuatan/daya oksidasi larutan tersebut, sifat noda, dan lamanya noda tersebut telah melekat pada alat kaca. Larutan pencuci yang telah digunakan beberapa kali jangan dicampurkan lagi dengan larutan pencuci stok. Larutan pencuci yang telah digunakan jangan langsung dibuang, tetapi simpan dalam botol berlabel.

Keberadaan laboratorium di Universitas dengan peralatan yang lengkap dan siap pakai, akan sangat membantu mahasiswa (pengguna) dalam belajar untuk memahami konsep, melakukan penelitian, memberi pengalaman nyata, dan membentuk keterampilan, sehingga mahasiswa akan menguasai kompetensi yang diharapkan yang berarti mutu lulusan meningkat.

\section{Penyimpanan Alat}

Penyimpanan alat hendaknya dibedakan antara alat-alat yang sering digunakan, alat-alat yang boleh diambil sendiri oleh mahasiswa, dan alat-alat yang mahal harganya. Prinsip yang perlu diperhatikan dalam penyimpanan alat di laboratorium adalah:

Aman

Alat yang mudah dibawa dan mahal harganya di samping itu juga peka dan mudah rusak, hendaknya disimpan tersendiri dalam laci atau lemari yang terkunci supaya aman dari pencuri dan kerusakan. Aman juga berarti tidak menimbulkan rusaknya alat sehingga fungsinya berkurang.

Mudah dicari

Penyimpanan alat memerlukan ruang penyimpanan dan perlengkapan seperti lemari, rak, dan laci yang ukurannya disesuaikan dengan luas ruangan yang tersedia. Untuk memudahkan mencari letak masingmasing alat, maka alat tersebut perlu diberi tanda yaitu dengan menggunakan label pada setiap tempat penyimpanan alat (lemari, rak, atau laci).

Mudah dicapai/diambil

Alat yang sering digunakan hendaknya disimpan sedemikian sehingga mudah diambil dan dikembalikan. Alat-alat seperti: rak tabung reaksi, kaki tiga, kasa asbes dan penjepit tabung reaksi dapat disimpan dalam laci atau lemari pada meja demonstrasi yang menghadap ke mahasiswa. Mahasiswa dapat mengambil dan mengembalikan sendiri alat-alat tersebut setelah mendapat petunjuk dari koordinator praktikum . Jika lemari meja tidak ada, dapat digunakan lemari pada dinding laboratorium.

Penyimpanan peralatan laboratorium dapat juga berdasarkan prinsip-prinsip:

Alat disimpan berdasarkan kelompok alat, misalnya berdasarkan jenis bahannya, seperti kelompok peralatan gelas, logam, kayu, karet, dan porselen.

Alat-alat disimpan berdasarkan frekuensi penggunaannya (sering digunakan dan jarang digunakan). Alat yang intensitas penggunaannya tinggi dipisahkan agar mudah dalam persiapan.

Alat-alat khusus disimpan dalam lemari/tempat khusus karena sifat alat yang rentan terhadap faktor luar/ sensitive dan mahal harganya.

Penyimpanan dan pemeliharaan alat juga harus memperhitungkan sumber kerusakan alat. Sumber kerusakan alat dan bahan akibat lingkungan meliputi hal-hal berikut: 
Kelembaban Udara, Air dan Asam-Basa, Suhu/ Perubahan Temperatur, Mekanis, Cahaya, Api, Debu atau Kotoran, Cara Penyimpanan Alat-Alat Kimia, Faktor Usia Alat (life time), Desain Alat dan Bahan Dasar Alat Itu Sendiri.

Pemeliharaan dan penyimpanan peralatan laboratorium kimia merupakan suatu proses kegiatan dalam rangka mengantisipasi terjadinya kerusakan sedini mungkin sehingga dapat meningkatkan efisiensi masa kerja peralatan yang digunakan.

Tujuan dari pemeliharaan dan penyimpanan peralatan laboratorium kimia :

Menjaga kondisi alat dalam keadaan baik, Memperpanjang umur pemakaian alat, Menjamin keamanan, keselamatan dan kenyamanan pengguna, Mengetahui gejala kerusakan alat sejak dini, Menghindari kerusakan alat, Memudahkan dalam menemukannya

\section{KESIMPULAN}

Pemeliharaan dan penyimpanan peralatan laboratorium kimia dengan baik dapat mencegah,terjadinya kerusakan pada peralatan laboratorium kimia.

\section{Saran}

Diharapkan semua PLP (Pranata Laboratorium Pendidikan) memiliki pengetahuan tentang teknik pemeliharaan dan penyimpanan peralatan laboratorium kimia dan juga mengikuti pelatihan sehingga dapat lebih terampil dalam mengelola peralatan di laboratorium.

\section{DAFTAR PUSTAKA}

Anonim. 2011. Panduan Teknis Perawatan Peralatan Laboratorium Kimia Sekolah Menengah Atas. Jakarta. Direktorat Pembinaan Sekolah Menengah Atas, Direktorat Jenderal Pendidikan Menengah Kementerian Pendidikan dan Kebudayaan.

Bartholomew, Rolland B and Crawlwey, Frak E. 1980. Science Laboratory Technique a Handbook for Teachers and Students, Menlo Park, California; Addison-Wesley Publishing Company.

Indrawati dkk. 1998/1999. Perawatan Preventif Sarana dan Prasarana Sekolah. Jakarta: Dikmenum. Indrawati dan Mamat Supriatna. 2007. Pemeliharaan Alat dan Bahan. PPPPTK IPA. Bandung Peraturan Menteri Pendidikan Nasional (PERMENDIKNAS) NO 24 Tahun 2007 Peraturan Menteri Pendidikan Nasional (PERMENDIKNAS) NO 26 Tahun 2009 